CENTRE POUR LA RECHERCHE ECONOMIQUE ET SES APPLICATIONS

\title{
WHO COMPARES TO WHOM ? THE ANATOMY OF INCOME COMPARISONS IN EUROPE
}

\author{
Andrew E. Clark ${ }^{(1)}$, Claudia Senik ${ }^{(2)}$
}

Version septembre 2009

Docweb no 0907

Andrew E. Clark ${ }^{(1)}$ : Paris School of Economics, 48 boulevard Jourdan, F-75014 Paris, Tél.: +33-143-13-63-29. E-mail: Andrew.Clark@ens.fr

Claudia Senik ${ }^{(2)}$ : Paris School of Economics, 48 boulevard Jourdan, F-75014 Paris, Tél.: +33-1-4313-63-12. E-mail: senik@pse.ens.fr 
Title : Who Compares to Whom? The Anatomy of Income Comparisons in Europe Author(s) : Andrew E. Clark, Claudia Senik

Abstract : This paper provides unprecedented direct evidence from large-scale survey data on both the intensity (how much?) and direction (to whom?) of income comparisons. Income comparisons are considered to be at least somewhat important by three-quarters of Europeans. They are associated with both lower levels of subjective well-being and a greater demand for income redistribution. The rich compare less and are more happy than average when they do, which latter is consistent with relative income theory. With respect to the direction of comparisons, colleagues are the most frequently-cited reference group. Those who compare to colleagues are happier than those who compare to other benchmarks; comparisons to friends are both less widespread and are associated with the lowest wellbeing scores. This is consistent with information effects, as colleagues' income arguably contains more information about the individual's own future prospects than do the incomes of other reference groups. Last, there is some evidence that reference groups are endogenous, with individuals tending to compare to those with whom they interact the most often.

Keywords : Income Comparisons, Relative Income, Reference Groups, Happiness, Redistribution, European Social Survey

JEL classification : D31, D63, 13, J31, Z13 


\title{
Who Compares to Whom? The Anatomy of Income Comparisons in Europe
}

\author{
Andrew E. Clark ${ }^{*}$ (Paris School of Economics and IZA) \\ Claudia Senik $^{* *}$ (Paris School of Economics and University Paris-Sorbonne)
}

September 2009

\begin{abstract}
This paper provides unprecedented direct evidence from large-scale survey data on both the intensity (how much?) and direction (to whom?) of income comparisons. Income comparisons are considered to be at least somewhat important by three-quarters of Europeans. They are associated with both lower levels of subjective well-being and a greater demand for income redistribution. The rich compare less and are more happy than average when they do, which latter is consistent with relative income theory. With respect to the direction of comparisons, colleagues are the most frequently-cited reference group. Those who compare to colleagues are happier than those who compare to other benchmarks; comparisons to friends are both less widespread and are associated with the lowest well-being scores. This is consistent with information effects, as colleagues' income arguably contains more information about the individual's own future prospects than do the incomes of other reference groups. Last, there is some evidence that reference groups are endogenous, with individuals tending to compare to those with whom they interact the most often.
\end{abstract}

Keywords: Income Comparisons, Relative Income, Reference Groups, Happiness, Redistribution, European Social Survey

JEL codes: D31, D63, I3, J31, Z13

* PSE, 48 Boulevard Jourdan, 75014 Paris, France. Tel.: +33-1-43-13-63-29. E-mail: Andrew.Clark@ens.fr. ${ }^{* *}$ PSE, 48 Boulevard Jourdan, 75014 Paris, France. Tel.: +33-143-13-63-12. E-mail: senik@pse.ens.fr.

The Norwegian Social Science Data Services (NSD) is the data archive and distributor of the ESS data. We are very grateful to seminar participants at the Royal Economic Society Conference (Warwick, 2009) and the Relativity, Inequality and Public Policy conference (Edinburgh, 2009) and three anonymous referees for very helpful comments. We thank CEPREMAP for financial support. 


\section{Who compares to whom? The anatomy of income comparisons in Europe}

\section{Introduction}

In two eponymous articles (1974, 1995), Dick Easterlin famously asked “Will raising the incomes of all improve the happiness of all?" and "Does economic growth improve the human lot?" To explain his (negative) empirical answer, he appealed to the phenomena of social comparisons and adaptation to income. The Easterlin paradox has subsequently produced a very lively empirical and theoretical literature revolving around the evidence for, and the implications of, income comparisons (either to others or to oneself in the past).

Both social comparisons and adaptation imply that utility is relative with respect to income, in the sense that individual well-being depends on the gap between the individual's actual income and some reference benchmark. There is by now a substantial empirical literature regarding the existence and composition of reference groups. However, outside of the laboratory, where the reference group can be directly controlled (as in Falk and Ichino, 2006, McBride, 2007 and Clark et al., 2009b), the vast majority of empirical papers have simply imposed a certain reference group as relevant for income comparison purposes (e.g. Cappelli and Sherer, 1988, Clark and Oswald, 1996, MacBride, 2001, Bygren, 2004, Ferrer-i-Carbonell, 2005, Luttmer, 2005, and Helliwell and Huang, 2009). Only rarely are different reference groups tested (as in Knight and Song, 2006), and direct survey evidence on the groups to which individuals compare is even scarcer. Knight and Song (2006) note that two-thirds of respondents in a survey of Chinese households report that their main comparison group consists of individuals in their own village. In a very recent paper, Senik (2009) exploits a survey of 25 post-Transition countries (LITS), where people were explicitly asked to compare their current living standard with that of various groups of people that they used to know before the transition started (i.e. before 1989). She finds that the greatest wellbeing impact comes from the deterioration in one's standard of living and from underperforming relative to one's former schoolmates or colleagues, rather than from more general comparisons such as the individual's self-ranking on the social ladder. 
In this paper we exploit new survey information from 18 European countries, which contains direct measures of both the intensity and the direction of income comparisons. With this novel information from Wave 3 of the European Social Survey (ESS3) we pursue three main objectives: (i) to provide new evidence on the extent and object of income comparisons across European countries; (ii) to establish the relationship between income comparisons and subjective well-being, and to interpret the results in the light of relative income theory; and (iii) to determine the empirical correlation between income comparisons and the demand for redistribution.

With respect to the intensity of income comparisons, existing empirical work almost always calculates an average effect over the whole sample, which is read off as the estimated coefficient on comparison income in a subjective well-being regression. Only rarely is any heterogeneity in the relationship between well-being and income addressed (one exception is the latent class analysis in Clark et al., 2005). Here we can ex ante identify groups who compare their income more and groups who compare their income less. We can also observe whether the direction of comparisons (the relevant benchmarks) varies across those groups.

The effect of income-comparison intensity on subjective well-being is a priori ambiguous. First, we might expect that this effect be more positive for those who have higher relative incomes, and we do indeed find some evidence in this respect. Second, and somewhat less directly, income comparisons may increase the well-being even of those who are relatively poor. The key distinction here is between non-Hirschman and Hirschman (1973) types of comparisons. The first of these covers "standard" envy effects: we are left less well-off when those in our reference group do better. The second refers to an "ambition" or "signal" effect whereby reference-group income contains information about the individual's own future prospects. Bringing these two together, others' good fortune likely continues to produce envy, but also contains a good-news element about oneself in the future. The net effect may then be negative, zero or positive, depending on the relative sizes of these status and signal phenomena.

For such information effects to pertain, those in the reference group have to share some of the characteristics that will likely influence the individual's own future income. Senik (2004 and 2008) provides evidence consistent with Hirschman-type information effects 
in high-mobility/uncertainty countries (Russia, the New Europe and the United States), showing that individual life satisfaction is positively correlated with the income of others in the same occupation. Equally, Clark et al. (2009a) appeal to linked Danish employer-employee data to suggest that the net satisfaction effect from the income of other workers in the same firm is actually positive. Both of these papers therefore consider professional reference groups, but neither is able to evaluate the effect of income comparisons to colleagues relative to those to friends or family members. The data available in ESS3 allow us to carry out such calculations, and we show below that the correlation between income comparisons and well-being is less negative when the former refers to colleagues. Last, Senik (2009) evaluates the different well-being effects of various kinds of comparisons: to past living standards, former colleagues, former high-schoolmates, parents and social rank. However, she has no information about how widespread these different types of comparisons are.

The ESS3 data then allows us to put all of these elements together, and investigate the relationship between income comparisons and individual well-being, depending on both the intensity and direction of these comparisons. We believe that this is the first example of this type of analysis, especially in the context of a large-scale cross-country dataset.

The paper is organized as follows. Section 2 describes the data and presents our interpretation of the answers to the income comparison questions in the light of relative income theory. Section 3 describes the intensity and direction (colleagues, family members, friends, other people) of income comparisons across Europe, insisting on the heterogeneity and endogeneity of reference groups (whereby individuals compare more to those with whom they interact more frequently). Section then 4 focuses on the correlation between income comparisons and subjective well-being, while Section 5 considers the relationship between income comparisons and the self-declared demand for redistribution. Finally, Section 6 concludes. 


\section{Data and the interpretation of income comparison questions}

A set of novel and useful questions appeared in Wave 3 of the European Social Survey (the ESS: freely available from http://www.europeansocialsurvey.org). The ESS is a multi-country survey which has covered 30 different countries at various points over its first three rounds. Wave 3 of the ESS contains a special module on well-being (see Huppert et al., 2009), in which the key income-comparison questions appeared. This wave, collected in 2006/2007, covers 24 different countries. We restrict the sample to those of working age (16-65) and we drop countries in which comparison and income variables are either missing (Cyprus) or not readily usable because they were measured and coded differently (Denmark, Estonia, Hungary, Romania and Ukraine), leaving us with 18 countries.

In the well-being module, after a series of various general questions about life satisfaction and personal values, a number of questions about work-life balance and several aspects of job satisfaction were asked of working respondents. The two incomecomparison questions appear here, and are thus asked uniquely of those who are in paid work. The final regression sample consists of around 19000 observations.

The intensity of income comparisons

The first comparison question is "How important is it for you to compare your income with other people's incomes?”. Individuals answered using a showcard, where 0 corresponds to "Not at all important", and 6 is labelled "Very important"; none of the intervening values are labelled. The weighted distribution of answers to this incomecomparison question across 18 European countries is shown in Table 1 below. 
Table 1. "How important is it for you to compare your income with other people's incomes?"

\begin{tabular}{lll}
\hline & Observations & $\%$ \\
\hline \multirow{2}{*}{ Not at all important } & 4765 & \\
1 & 2998 & 25.0 \\
2 & 2686 & 15.7 \\
3 & 3250 & 14.1 \\
4 & 2601 & 17.1 \\
5 & 1800 & 13.7 \\
Very important & 953 & 9.5 \\
& & 5.0 \\
Total & 19053 & 100.0 \\
\hline Note: Weighted statistics. Sample: In paid work aged between 16 and 65.
\end{tabular}

Note: Weighted statistics. Sample: In paid work aged between 16 and 65.

Table 1 shows that for a quarter of Europeans in this sample, it is "not at all important" to compare their incomes to others. In general there is something of a left-skew in the distribution of comparison intensity, but there are still substantial numbers of individuals towards the top end of the distribution, with 28 per cent of respondents declaring that comparisons are important (with answers of 4 to 6 on the 0 to 6 scale).

The direction of income comparisons

The third wave of the ESS also includes the following question: "Whose income would you be most likely to compare your own with? Please choose one of the groups on this card: Work colleagues/ Family members/ Friends/ Others/ Don't compare/ Not applicable/ Don't know." The distribution of answers to this question is shown in Table 2.

Table 2. "Whose income would you be most likely to compare your own with?"

\begin{tabular}{lll}
\hline & Observations & $\%$ \\
Work colleagues & 6874 & 36.3 \\
Family members & 1103 & 5.8 \\
Friends & 2825 & 14.9 \\
Others & 1344 & 7.1 \\
Don't compare & 6789 & 35.9 \\
& & \\
Total & 18936 & 100.0 \\
\hline
\end{tabular}

Note: Weighted statistics. Sample: In paid work aged between 16 and 65. 
Of those who identify a comparison group, the majority compare to their work colleagues or (to a far lesser extent) their friends. Partial correlations (not shown) suggest that the greater the intensity of income comparisons, the more likely that the respondent designates colleagues as her reference group. More than a third of respondents say that they do not compare (Table 2). The correlation between declaring that one "does not compare" (Table 2) and that "comparisons are not at all important" (Table 1) is not perfect (it is equal to 0.45 ) as the questions reflect two different things. Even so, the cross-tabulations in Table 3 reveal that $73 \%$ of those who declare that comparisons are not at all important also say that they "Don't compare”.

Table 3. The Intensity and Direction of Income Comparisons (\%)

\begin{tabular}{lllllll}
\hline Comparisons & $\begin{array}{l}\text { Work } \\
\text { colleagues }\end{array}$ & $\begin{array}{l}\text { Family } \\
\text { members }\end{array}$ & Friends & Others & $\begin{array}{l}\text { Don't } \\
\text { compare }\end{array}$ & Total \\
Not at all important & 16.1 & 4.1 & 5.5 & 1.8 & 72.6 & 100.0 \\
& 10.9 & 17.4 & 9.1 & 6.3 & 50.9 & 24.9 \\
$\mathbf{1}$ & 28.9 & 6.8 & 10.0 & 4.4 & 50.0 & 100.0 \\
& 12.4 & 18.2 & 10.5 & 9.6 & 22.1 & 15.7 \\
$\mathbf{2}$ & 42.4 & 7.6 & 15.8 & 5.8 & 28.4 & 100.0 \\
& 16.4 & 18.3 & 14.9 & 11.5 & 11.3 & 14.1 \\
$\mathbf{3}$ & 44.1 & 6.4 & 20.5 & 9.2 & 19.8 & 100.0 \\
& 20.5 & 18.5 & 23.4 & 21.9 & 9.5 & 17.0 \\
$\mathbf{4}$ & & & & & & \\
& 51.7 & 5.8 & 23.1 & 10.8 & 8.6 & 100.0 \\
$\mathbf{5}$ & 19.3 & 13.6 & 21.1 & 20.7 & 3.3 & 13.7 \\
& & & & & & 100.0 \\
Very important & 51.9 & 5.4 & 22.0 & 13.4 & 7.3 & 9.6 \\
& 13.6 & 8.8 & 14.0 & 18.0 & 2.0 & 100.0 \\
Total & 49.6 & 6.0 & 20.9 & 17.1 & 6.5 & 5.1 \\
& 6.9 & 5.1 & 7.0 & 12.1 & 0.9 & 100.0 \\
\hline
\end{tabular}

Notes: Weighted statistics. Sample: In paid work aged between 16 and 65. The first figure in each cell refers to the row percentage and the second to the column percentage. 
Comparisons and relative income theory

As well as describing the prevalence of income comparisons in Europe, we also try to interpret them in the light of relative income theory. A well-being function including a relative income term can be written as follows:

$\mathrm{U}_{\mathrm{i}}=\mathrm{U}_{\mathrm{i}}\left(\mathrm{y}_{\mathrm{i}}, \mathrm{y}_{\mathrm{i}}-\mathrm{y}_{\mathrm{i}}^{*}, \underline{\mathrm{X}}_{\mathrm{i}}, \ldots\right)$

where $\mathrm{U}_{\mathrm{i}}$ is the well-being of individual $i, \mathrm{y}_{\mathrm{i}}$ is her own income, $\mathrm{y}_{\mathrm{i}}{ }^{*}$ is the income of her reference group, and $\underline{X}_{i}$ is the vector of the usual socio-economic correlates of subjective well-being (Di Tella and MacCulloch, 2003).

The proxy measure of individual well-being, $U_{i}$, used here is the answer to the happiness question which appears in the ESS3. Respondents answered the question “How happy are you?” by ticking a response on an 11-step ladder, where 0 was labelled “extremely unhappy” and 10 "extremely happy”. The distribution of responses is shown in Table 4 below.

Table 4. "How happy are you?”

\begin{tabular}{lcc}
\hline & Frequency & \% \\
\hline Extremely unhappy & 49 & 0.3 \\
1 & 89 & 0.5 \\
2 & 176 & 0.9 \\
3 & 361 & 1.9 \\
4 & 462 & 2.4 \\
5 & 1683 & 8.9 \\
6 & 1526 & 8.1 \\
7 & 3747 & 19.8 \\
8 & 5722 & 30.2 \\
9 & 3337 & 17.6 \\
Extremely happy & 1813 & 9.6 \\
& & \\
Total & 18966 & 100.0 \\
\hline
\end{tabular}

Note: Weighted statistics. Sample: In paid work aged between 16 and 65.

Empirical work in this area commonly considers that the relationship between wellbeing and income (or log income) is linear. In the first case, equation (1) is parameterized as:

$\mathrm{U}_{\mathrm{i}}=\alpha+\beta \cdot \mathrm{y}_{\mathrm{i}}+\gamma \cdot\left(\mathrm{y}_{\mathrm{i}}-\mathrm{y}_{\mathrm{i}}^{*}\right)+\underline{\delta} \cdot \underline{\mathrm{X}}_{\mathrm{i}}+\varepsilon_{\mathrm{i}}$ 
where $\varepsilon_{\mathrm{i}}$ is an error term with standard properties. Information on $\mathrm{y}_{\mathrm{i}}$ is obtained from the dataset at hand; some reference group is then typically posited by the researcher, and $\mathrm{y}_{\mathrm{i}}{ }^{*}$ is either constructed from within the dataset, or matched in from some other source. The estimation of equation (1') yields estimates of $\beta$ and $\gamma$, which reflect the strength of the correlation between the well-being measure $\left(\mathrm{U}_{\mathrm{i}}\right)$ and $\mathrm{y}_{\mathrm{i}}$ and $\left(\mathrm{y}_{\mathrm{i}}-\mathrm{y}_{\mathrm{i}}{ }^{*}\right)$ respectively. Both of these are average effects estimated over the whole sample. Equally, with respect to the latter, the nature of the reference group used to calculate $\mathrm{y}_{\mathrm{i}}{ }^{*}$ is considered to be the same for all individuals. However, there are few a priori grounds for the exclusion of heterogeneity, both regarding comparison intensity and the composition of the reference group. Indeed, existing work (Falk and Knell, 2004, and Wood and Taylor, 1991) has suggested that different reference groups in the population reflect diverse coping strategies such as self-enhancement and self-improvement. One major advantage of the third wave of the ESS is that it contains direct information on individual heterogeneity in both of these dimensions.

To interpret the ESS comparison-intensity variable, we slightly rewrite equation (1') above, replacing the direct linear effect of $\mathrm{y}_{\mathrm{i}}-\mathrm{y}_{\mathrm{i}}$ * on $\mathrm{U}_{\mathrm{i}}$ by some general function $\mathrm{f}($.$) , and$ introducing individual-level heterogeneity into this relationship.

$\mathrm{U}_{\mathrm{i}}=\alpha+\beta \mathrm{y}_{\mathrm{i}}+\gamma_{\mathrm{i}} \cdot \mathrm{f}\left(\mathrm{y}_{\mathrm{i}}-\mathrm{y}_{\mathrm{i}}^{*}\right)+\underline{\delta}^{\prime} \cdot \underline{X}_{\mathrm{i}}+\varepsilon_{\mathrm{i}}$

The ESS income-comparison intensity variable is argued to provide us with a direct measure of this $\gamma_{\mathrm{i}}$.

Along the same lines, respondents' answers about the reference group to which they are most likely to compare yield information on the way in which $\mathrm{y}_{\mathrm{i}}{ }^{*}$ is formed across individuals, so that we can rewrite (2) as:

$\mathrm{U}_{\mathrm{i}}=\alpha+\beta \mathrm{y}_{\mathrm{i}}+\gamma_{\mathrm{i}} \cdot \mathrm{f}\left(\mathrm{y}_{\mathrm{i}}-\mathrm{y}^{*}\left(\mathrm{k}_{\mathrm{i}}\right)\right)+\underline{\delta}^{\prime} \cdot \underline{\mathrm{X}}_{\mathrm{i}}+\varepsilon_{\mathrm{i}}$

where $\mathrm{k}_{\mathrm{i}}$ is a parameter indicating the direction of comparison, and thus the way in which reference group income is calculated, for each individual.

If we estimate a well-being equation, such as (2), with comparison intensity as an explanatory variable (but no measure of relative income), the estimated coefficient will 
indicate the average sign of $\mathrm{f}\left(\mathrm{y}_{\mathrm{i}}-\mathrm{y}_{\mathrm{i}}{ }^{*}\right)$ across the whole sample; the analogous estimation of equation (3) tells us whether different income reference groups are correlated with individual well-being in the same way.

With respect to the first of these empirical questions, we have no unambiguous prior regarding the sign of $f\left(y_{i}-y_{i}{ }^{*}\right)$. This sign will first depend on the type of interaction that is at work (i.e. the nature of $f()$.$) as reference-group income \left(y_{i}{ }^{*}\right)$ rises: envy (where $f^{\prime}($. $>0$ ) or information (where $\mathrm{f}^{\prime}()<$.0 ), as discussed in Section 1. Second, the impact of social comparisons of income on well-being very likely depends on the individual's own income: some do well from such comparisons, others less well. One direct implication of equation (2) under envy is that the correlation between the importance of comparisons and well-being should be more positive for those with higher incomes, for a given level of reference income. Third, the sign of this correlation will likely depend on the way in which $\mathrm{y}_{\mathrm{i}}{ }^{*}$ is formed. Suppose that there are no information effects and all comparisons are downwards, i.e. everyone compares only to people who are poorer than them, perhaps for self-enhancement reasons (Falk and Knell, 2004). We should then find a positive relationship between the intensity of income comparisons and subjective well-being (as $\mathrm{y}_{\mathrm{i}}>\mathrm{y}_{\mathrm{i}} *$ for everyone). Analogously, if income comparisons are rather upward, as suggested by Duesenberry (1949), greater income-comparison intensity will go hand-in-hand with lower well-being. In this interpretative framework, an average negative estimated coefficient on $\gamma_{i}$ suggests that most comparisons are upward (so that $\mathrm{y}_{\mathrm{i}}-\mathrm{y}_{\mathrm{i}}$ * is predominantly negative), whereas a positive average coefficient is consistent with downward comparisons.

Overall, the relationship between comparison intensity and well-being can be either positive or negative. With envy and mostly upwards comparisons we expect a negative correlation between well-being and the importance of comparisons, whereas both envy with downward comparisons and information effects will yield a positive correlation. In practice, our empirical results below identify a significant negative coefficient on the importance of comparisons.

In an ideal dataset, we would be able to combine information on both own income $\mathrm{y}_{\mathrm{i}}$ and reference income $\mathrm{y}_{\mathrm{i}}{ }^{*}$, with our measure of comparison intensity $\left(\gamma_{\mathrm{i}}\right)$, and in 
particular isolate the effect of the latter according to the value of $y_{i}-y_{i}^{*}$. However, as for almost all datasets, the ESS3 data do not contain any direct information on the level of reference income itself, and the relatively crude income measure here (income bands) precludes the calculation of a measure of reference income from within the database.

\section{Statistical Specification}

The multivariate analysis of well-being and the intensity and direction of income comparisons is carried out via OLS regressions, using a standard set of individual sociodemographic controls as well as country dummies. Income is measured at the household level in the ESS, and is banded into eleven categories (see the descriptive statistics in the Appendix). In the basic regressions, we include log income, which we calculate using the mid-point of each income bracket. For the lowest income band, we assign a value of half of the upper bound (75 Euros), and for the highest income category a value of 1.5 times the lower bound (10000 Euros). As the dependent variable is ordinal, rather than cardinal, we should ideally carry out ordered probit or logit analyses. It turns out that the results from cardinal analysis using OLS are very similar to those from ordinal analysis (as in Ferrer-i-Carbonell and Frijters, 2004), and for ease of interpretation we present the former here.

\section{The Intensity and Direction of Income Comparisons}

As the main advantage of the ESS data here is arguably to offer direct information on heterogeneity in income-comparison intensity and direction, we start with a simple description of these two novel variables.

The intensity of income comparisons

To illustrate the degree of income comparisons, we assign the cardinal numbers zero to six to the individual replies detailed in Table 1, and calculate the average intensity of income comparisons by country. Countries with higher average scores therefore attach more importance to income comparisons. Figure 1 depicts these country averages, 
ordered from the least to the most comparison-sensitive. Although it is difficult to establish very precise country patterns, most Eastern European countries are found on the right-hand side of this figure, whereas Switzerland and Austria appear towards the left-hand side. Figure 1 also shows the level of Real GDP per capita, taken from the latest available Penn Table (Heston et al., 2006). Visual inspection of Figure 1 suggests a negative correlation between average GDP per capita and comparison intensity across countries. As we will show below, the same observation holds within countries as well: individuals with lower incomes seem to attach more weight to income comparisons.

Figure 1. "How important is it to you to compare your income with other people's incomes?”

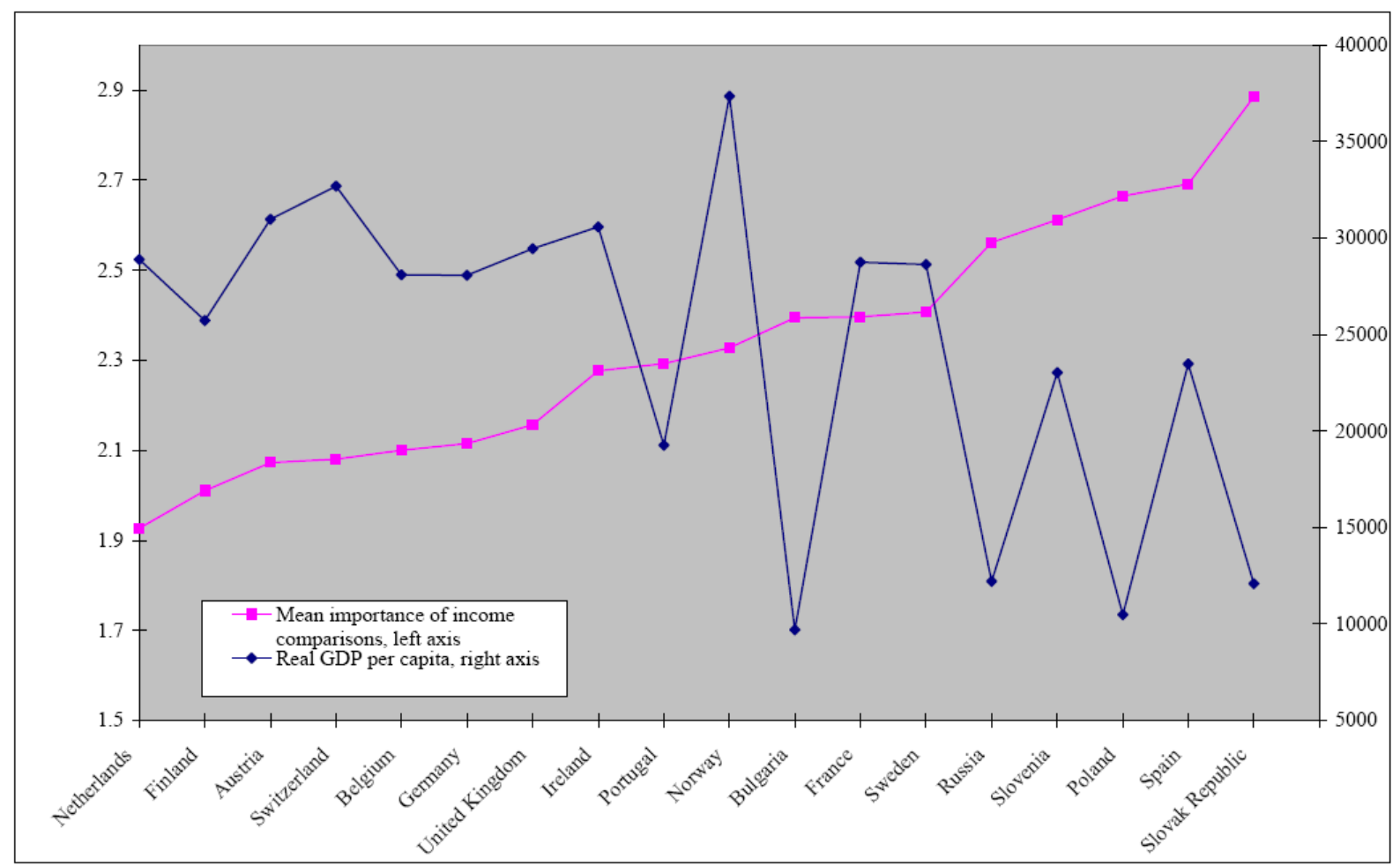

Notes: Average weighted income comparison by country (on a 0-6 scale). Real Gross Domestic Product per Capita in 2004, in current dollar prices, source: Heston, Summers and Aten, Penn World Table, 2006.

Table 5 provides an individual-level analysis of comparison intensity (which we identify with the $\gamma_{i}$ parameter in equation (2)). Those who live in lower-income households compare their incomes more (this relationship is non-linear and is stronger at the lower end of the income distribution, as income appears in logs here). 
The self-employed (who constitute $12 \%$ of the sample) compare their incomes significantly less than do employees; beyond this, most of the occupational variables are insignificant. The single compare more, but there is no significant gender difference in the intensity of income comparisons. The country dummies are very significant, and show that, compared to Austria, Finland and the Netherlands, respondents in other countries, and in particular Eastern European countries (Poland, Russia, Slovenia, and Slovakia) attach more weight to comparisons. The ranking of the estimated coefficients on the country dummies is similar to that illustrated in Figure 1. We also carried out separate regressions by country, despite the rather small resulting sample sizes: these did not reveal any overall startling differences between countries.

Table 5. The Importance of Income Comparisons. OLS estimates

\begin{tabular}{|c|c|c|}
\hline \multicolumn{3}{|c|}{ "How important is it to you to compare your income with other people's incomes?” } \\
\hline & Coefficient & Standard error \\
\hline Male & -0.020 & $(0.038)$ \\
\hline Log household income & $-0.062 * *$ & $(0.028)$ \\
\hline \multicolumn{3}{|l|}{ Age (omitted: 16-25) } \\
\hline $25-50$ & 0.025 & $(0.088)$ \\
\hline over 50 & -0.158 & $(0.095)$ \\
\hline \multicolumn{3}{|c|}{ Education (omitted: Primary) } \\
\hline Secondary & -0.059 & $(0.051)$ \\
\hline Tertiary & $0.176^{* *}$ & $(0.062)$ \\
\hline \multicolumn{3}{|c|}{ Marital status (omitted: Never in a couple) } \\
\hline Married & $-0.109 * *$ & $(0.051)$ \\
\hline Separated & $-0.200 * * *$ & $(0.057)$ \\
\hline Widow & -0.190 & $(0.113)$ \\
\hline Ever given birth to child & 0.018 & $(0.040)$ \\
\hline \multicolumn{3}{|l|}{ Country (omitted: Austria) } \\
\hline Belgium & 0.015 & $(0.027)$ \\
\hline Bulgaria & $0.203^{* * *}$ & $(0.062)$ \\
\hline Finland & $-0.077 * *$ & $(0.033)$ \\
\hline France & $0.250 * * *$ & $(0.020)$ \\
\hline Germany & $0.072^{* *}$ & $(0.031)$ \\
\hline Ireland & $0.173 * * *$ & $(0.031)$ \\
\hline Netherlands & $-0.169 * * *$ & $(0.026)$ \\
\hline Norway & $0.256 * * *$ & $(0.042)$ \\
\hline Poland & $0.472 * * *$ & $(0.038)$ \\
\hline Portugal & $0.179 * * *$ & $(0.025)$ \\
\hline Russia & $0.348 * * *$ & $(0.060)$ \\
\hline
\end{tabular}




\begin{tabular}{lll}
\hline Slovakia & $0.828^{* * *}$ & $(0.038)$ \\
Slovenia & $0.501^{* * *}$ & $(0.021)$ \\
Spain & $0.607 * * *$ & $(0.010)$ \\
Sweden & $0.329 * * *$ & $(0.035)$ \\
Switzerland & 0.026 & $(0.037)$ \\
United Kingdom & $0.123^{* * *}$ & $(0.024)$ \\
Self-Employed (as opposed to employees) & & \\
& $-0.581^{* * *}$ & $(0.040)$ \\
Occupation (omitted: Elementary professions) & & \\
Armed Forces & & $(0.249)$ \\
Legislators, senior officials and managers & $-0.683^{* *}$ & $(0.120)$ \\
Professionals & -0.114 & $(0.084)$ \\
Technicians and associate professionals & 0.010 & $(0.084)$ \\
Clerks & -0.018 & $(0.103)$ \\
Service workers and shop and market sales workers & -0.088 & $(0.141)$ \\
Skilled agricultural and fishery workers & -0.161 & $(0.106)$ \\
Craft and related trades workers & $0.311^{* *}$ & $(0.102)$ \\
Plant and machine operators and assemblers & 0.001 & \\
Observations & -0.032 & \\
R-squared & & \\
\hline
\end{tabular}

Notes: $*, * *$ and $* * *$ denote significance at the $10 \%, 5 \%$ and $1 \%$ levels respectively.

Standard errors in parentheses are clustered by country.

\section{Who compares to whom?}

While it is very useful to have information on the general intensity of income comparisons, as described above, we would also like to know to whom people actually compare, i.e. whose incomes appear in $\mathrm{y}^{*}\left(\mathrm{k}_{\mathrm{i}}\right)$ ? If reference groups are to an extent endogenous, they will likely depend on the respondent's age, marital status, labour market status, and so on. To investigate, Table 6 presents the results of a multinomial logit regression of the choice of reference group. The coefficients here reflect the probability of choosing the given reference group relative to the omitted category (“work colleagues”).

Table 5 suggested that the self-employed were less likely to compare in general. Table 6 nuances this result by showing that they are significantly less likely to compare to their colleagues, but more likely to compare to family members, friends and “others”. Almost all employees (except those in agriculture), compare more to their colleagues than do those in the omitted category (elementary occupations); this is especially true for those in more professional occupations. 
With respect to the demographic variables, men compare less to family members than do women. Comparisons to colleagues (and “others") increase after the age of 25, whereas the opposite is true of comparisons to family members and friends. The married compare more to family members and friends, and individuals with children compare more to family members. The results here are consistent with the comparison benchmark partly reflecting the kinds of regular social interactions that individuals experience.

Regarding the country dummies, individuals in central Continental Europe compare more to their colleagues, while the Spanish, Irish, Polish and Finnish compare more to family members. Those in Eastern Europe (except Poland) compare significantly less to their family than do others.

Table 6. "Whose income would you be most likely to compare your own with?" Multinomial logit regression. Omitted category: "Work colleagues".

\begin{tabular}{|c|c|c|c|c|c|c|c|c|}
\hline & Family & lembers & & & & & Don't c & mpare \\
\hline Male & $\begin{array}{l}\text { Coef. } \\
\mathbf{- 0 . 4 5 2}\end{array}$ & $\begin{array}{l}\text { Std.err. } \\
(0.098)\end{array}$ & $\begin{array}{l}\text { Coef. } \\
0.052\end{array}$ & $\begin{array}{l}\text { Std.err. } \\
(0.071)\end{array}$ & $\begin{array}{l}\text { Coef. } \\
\text { 0.157 }\end{array}$ & $\begin{array}{l}\text { Std.err. } \\
(0.094)\end{array}$ & $\begin{array}{l}\text { Coef. } \\
-0.026\end{array}$ & $\begin{array}{l}\text { Std.err. } \\
(0.067)\end{array}$ \\
\hline Log household income & -0.011 & $(0.066)$ & -0.040 & $(0.049)$ & -0.137 & (0.049) & -0.053 & (0.049) \\
\hline Age (omitted: 16-25) & & & & & & & & \\
\hline Age 25-50 & -0.532 & $(0.148)$ & -0.751 & $(0.110)$ & 0.165 & $(0.126)$ & -0.083 & $(0.111)$ \\
\hline Age over 50 & -0.638 & $(0.161)$ & -1.216 & $(0.160)$ & 0.241 & $(0.141)$ & 0.200 & $(0.099)$ \\
\hline Education (omitted : Primary) & & & & & & & & \\
\hline Secondary education & -0.030 & $(0.102)$ & -0.059 & $(0.075)$ & -0.136 & $(0.119)$ & -0.097 & $(0.066)$ \\
\hline Tertiary education & 0.082 & $(0.157)$ & -0.001 & $(0.106)$ & -0.012 & (0.109) & -0.319 & $(0.093)$ \\
\hline $\begin{array}{l}\text { Marital status (omitted: Never in } \\
\text { couple) }\end{array}$ & & & & & & & & \\
\hline Married & 0.333 & $(0.102)$ & -0.291 & $(0.082)$ & -0.010 & $(0.109)$ & 0.227 & $(0.056)$ \\
\hline Separated & -0.111 & $(0.182)$ & -0.237 & $(0.091)$ & -0.008 & $(0.109)$ & 0.278 & $(0.063)$ \\
\hline Widowed & -0.269 & (0.353) & 0.020 & $(0.231)$ & -0.081 & $(0.278)$ & 0.308 & $(0.178)$ \\
\hline Ever Had Children & 0.211 & $(0.106)$ & -0.147 & $(0.094)$ & 0.177 & $(0.094)$ & 0.021 & $(0.058)$ \\
\hline Country (omitted: Austria) & & & & & & & & \\
\hline Belgium & -0.144 & $(0.061)$ & -0.370 & $(0.054)$ & 0.580 & $(0.054)$ & -0.031 & $(0.035)$ \\
\hline Bulgaria & -1.434 & $(0.165)$ & 0.082 & $(0.102)$ & 1.143 & $(0.133)$ & 0.013 & $(0.123)$ \\
\hline Finland & -0.291 & $(0.070)$ & 0.043 & $(0.068)$ & 0.070 & $(0.062)$ & -0.170 & $(0.046)$ \\
\hline France & -0.551 & $(0.075)$ & -0.217 & $(0.050)$ & 0.651 & $(0.065)$ & -0.008 & $(0.039)$ \\
\hline Germany & 0.389 & $(0.039)$ & 0.143 & $(0.026)$ & 0.578 & $(0.021)$ & 0.353 & $(0.019)$ \\
\hline Ireland & 0.423 & $(0.063)$ & -0.109 & $(0.049)$ & 0.718 & $(0.058)$ & -0.779 & $(0.036)$ \\
\hline Netherlands & 0.047 & $(0.048)$ & -0.677 & $(0.035)$ & 0.323 & $(0.032)$ & -0.161 & $(0.022)$ \\
\hline Norway & 0.115 & $(0.059)$ & 0.040 & (0.052) & 0.333 & (0.033) & -0.298 & (0.032) \\
\hline Poland & 0.211 & $(0.037)$ & -0.120 & $(0.049)$ & 0.167 & $(0.050)$ & -0.014 & $(0.032)$ \\
\hline Portugal & -0.352 & $(0.032)$ & -0.297 & $(0.041)$ & 0.431 & $(0.044)$ & -0.011 & $(0.029)$ \\
\hline Russia & -1.059 & $(0.087)$ & -0.416 & $(0.064)$ & 0.059 & (0.065) & -1.203 & $(0.050)$ \\
\hline Slovakia & 0.507 & $(0.089)$ & 0.688 & $(0.061)$ & 0.905 & (0.074) & 0.201 & (0.068) \\
\hline
\end{tabular}




\begin{tabular}{|l|ll|ll|ll|ll|}
\hline Slovenia & $\mathbf{- 0 . 3 2 3}$ & $(0.050)$ & $\mathbf{- 1 . 3 0 9}$ & $(0.035)$ & $\mathbf{- 0 . 3 4 9}$ & $(0.034)$ & $\mathbf{- 0 . 4 6 7}$ & $(0.031)$ \\
Spain & $\mathbf{- 0 . 5 6 3}$ & $(0.158)$ & 0.103 & $(0.100)$ & $\mathbf{- 0 . 5 8 4}$ & $(0.130)$ & -0.105 & $(0.118)$ \\
Sweden & $\mathbf{- 0 . 6 7 2}$ & $(0.061)$ & $\mathbf{- 1 . 1 2 2}$ & $(0.048)$ & $\mathbf{- 0 . 4 0 5}$ & $(0.060)$ & $\mathbf{- 1 . 2 7 6}$ & $(0.036)$ \\
Switzerland & $\mathbf{- 0 . 2 9 8}$ & $(0.056)$ & $\mathbf{- 0 . 4 9 0}$ & $(0.035)$ & $\mathbf{- 0 . 1 8 4}$ & $(0.047)$ & $\mathbf{- 0 . 5 0 3}$ & $(0.034)$ \\
United Kingdom & -0.886 & $(0.107)$ & $\mathbf{- 0 . 8 7 4}$ & $(0.061)$ & $\mathbf{0 . 1 3 8}$ & $(0.095)$ & $\mathbf{- 0 . 3 9 0}$ & $(0.072)$ \\
Self-employed & $\mathbf{0 . 5 3 3}$ & $(0.155)$ & $\mathbf{0 . 9 6 3}$ & $(0.124)$ & $\mathbf{0 . 9 0 0}$ & $(0.134)$ & $\mathbf{1 . 2 6 9}$ & $(0.081)$ \\
Occupation (omitted: Elementary) & & & & & & & & \\
Legislators, senior officials and & $\mathbf{- 0 . 8 3 7}$ & $(0.242)$ & 0.012 & $(0.131)$ & $\mathbf{0 . 3 9 0}$ & $(0.137)$ & -0.097 & $(0.117)$ \\
managers & & & & & & & & \\
Professionals & $\mathbf{0 . 9 9 6}$ & $(0.191)$ & $\mathbf{- 0 . 3 2 0}$ & $(0.106)$ & 0.082 & $(0.191)$ & $\mathbf{- 0 . 4 9 7}$ & $(0.087)$ \\
Technicians and associate professionals & $\mathbf{- 0 . 8 9 9}$ & $(0.177)$ & $\mathbf{- 0 . 3 0 4}$ & $(0.108)$ & -0.055 & $(0.163)$ & $\mathbf{- 0 . 4 6 9}$ & $(0.080)$ \\
Clerks & $\mathbf{- 0 . 7 4 2}$ & $(0.152)$ & -0.167 & $(0.150)$ & -0.317 & $(0.193)$ & $\mathbf{- 0 . 3 0 0}$ & $(0.152)$ \\
Service workers and shop and market & $\mathbf{- 0 . 4 2 2}$ & $(0.134)$ & -0.016 & $(0.123)$ & 0.198 & $(0.149)$ & -0.099 & $(0.127)$ \\
sales workers & & & & & & & & \\
Skilled agricultural and fishery workers & -0.150 & $(0.313)$ & -0.113 & $(0.291)$ & 0.416 & $(0.347)$ & $\mathbf{- 0 . 4 2 2}$ & $(0.191)$ \\
Craft and related trades workers & $\mathbf{- 0 . 5 4 6}$ & $(0.174)$ & $\mathbf{- 0 . 3 0 2}$ & $(0.123)$ & -0.185 & $(0.166)$ & $\mathbf{- 0 . 4 6 7}$ & $(0.105)$ \\
Plant and machine operators and & $\mathbf{- 0 . 6 0 3}$ & $(0.209)$ & $\mathbf{- 0 . 3 0 3}$ & $(0.092)$ & $\mathbf{- 0 . 3 3 4}$ & $(0.145)$ & $\mathbf{- 0 . 4 9 9}$ & $(0.104)$ \\
assemblers & & & & & & & & \\
Constant & -0.570 & $(0.510)$ & 0.760 & $(0.406)$ & $\mathbf{- 1 . 2 5 0}$ & $(0.412)$ & $\mathbf{0 . 7 4 0}$ & $(0.396)$ \\
Observations & 13539 & & & & & & & \\
Pseudo R2 & 0.0568 & & & & & & & \\
Log Pseudolikelihood & -17574 & & & & & & & \\
\hline
\end{tabular}

Notes: Multinomial logit regressions of the answer to the question "Whose income would you be most likely to compare your own with?” The possible answers are Work colleagues (the omitted category), Family members, Friends, Others, Don't compare, Not applicable, and Don't know. The 32 observations on members of the Armed Forces are dropped here, as only one chose Family as the comparison group. Standard errors in parentheses are clustered by country. Bold coefficients are significant at the five per cent level or better.

To explore a little more the idea that reference groups reflect the type of social interactions that individuals experience, we appeal to a number of other questions that appear in the ESS (the exact formulation of these questions and the distribution of the answers to them are shown in the Appendix). The specific regression results are not shown here due to space constraints, but are available on request. These findings are summarised in Table 11 at the end of the paper.

- Those with no internet access (23\% of the sample) attach less importance to income comparisons.

- Those who spend more than one hour per weekday watching TV (72\% of the sample) compare more in general, especially to "others".

- City-dwellers (rather than country villages or countryside) constitute $60 \%$ of the sample and compare more, especially to “friends”. 
- People who have never had a paid job ( $9 \%$ of the total sample) compare less.

- Those who work in small firms with less than 100 employees (64\% of the sample) compare less in general. They compare less to their colleagues and more to friends and family members.

- The intensity of comparisons (in particular to colleagues, but not to friends) rises with contractual hours of work per week.

- Those in households whose main income source is transfers compare less (and rather to friends) than do those whose main household income source is wages (who compare more to colleagues).

- People who declare that they often "meet socially", are more likely to compare to friends, and less to colleagues; they also attach less importance to income comparisons in general.

- Those who declare that it is "very much like them" to think that "it is important in life to be successful and that people recognize achievements" and those who agree that "it is important in life to be rich, have money and buy expensive things” compare significantly more, and in particular to their colleagues.

To sum up, when talking about "income comparisons", most people seem to have in mind comparisons to colleagues, rather than to other non-professional groups. However, beyond this broad statement, comparison benchmarks seem to be partly endogenous: people compare to the groups with whom they interact more frequently.

\section{Comparisons and Well-Being}

Income comparisons therefore seem to part of the life of a majority of people, with the specific comparison benchmark varying according to the individual's own labourmarket and social position. We now ask whether there is any correlation between income comparisons and well-being. We do so by estimating equations (2) and (3), with self-declared happiness as a proxy measure of $U_{i}$. 
We first check that the estimated happiness function is "well-behaved" in terms of the usual correlates of subjective well-being (see Clark et al., 2008b). The regression results (not shown for space reasons) confirm that self-declared happiness is indeed higher for richer and younger people, the married, women (although not significantly so in Southern and Eastern Europe) and for more professional occupations. Those in Scandinavian countries report the highest happiness scores, and those in Eastern Europe the lowest.

Table 7. Happiness and Income Comparisons (OLS)

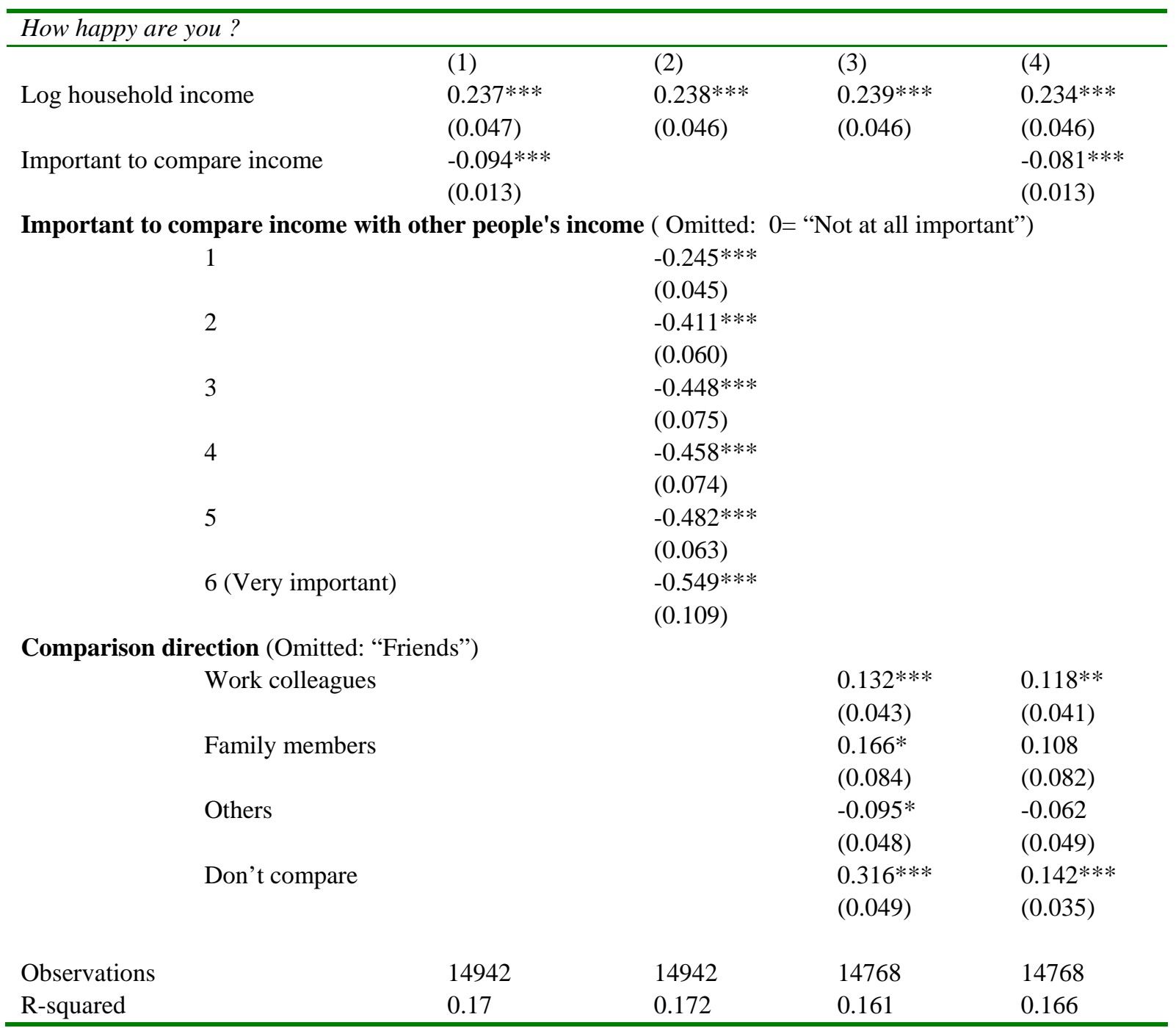

Notes: $*, * *$ and $* * *$ denote significance at the $10 \%, 5 \%$ and $1 \%$ levels respectively. Standard errors in parentheses are clustered by country. Other controls as in Table 5: gender, 10 occupation dummies, self-employed, 3 age categories, 3 education categories, 5 marital status categories, a dummy for those who ever had a child, and country dummies. 


\subsection{Those who compare more are less happy}

There is a negative and significant correlation between comparison intensity and subjective happiness (Table 7). In column 1, the income comparison intensity is treated simply as a cardinal variable, and attracts a coefficient of -0.094: each step on the comparison intensity-scale is associated with happiness that is lower by about one-tenth of a step on the 0-10 happiness scale. The cardinality of comparisons is relaxed in column 2, where dummies for comparison intensity are introduced: the estimated coefficients on these dummies are monotonic, and again show that happiness falls with comparison intensity.

This negative relationship between comparison intensity and happiness can be reproduced for a variety of additional well-being questions in the ESS, namely "Satisfaction with life as a whole", "Satisfaction with how life turned out so far", Subjective overall health, "Feeling of depression during the past week", "Feeling always optimistic about my future”, as well as the more economic notions of satisfaction represented by "Satisfaction with one's standard of living”, "Difficulty of living with present income", "Satisfaction with job" and feeling that one "gets paid appropriately, considering efforts and achievements" (see the Appendix for the descriptive statistics of these variables). In all cases, the greater the intensity of comparisons (entered cardinally for ease of presentation), the lower the well-being score (see Table 8). 
Table 8. Alternative Well-Being Measures and Comparison Intensity (OLS)

\begin{tabular}{|c|c|c|c|c|c|}
\hline & How happy are you & $\begin{array}{c}\text { How satisfied } \\
\text { with life as a } \\
\text { whole }\end{array}$ & $\begin{array}{l}\text { Satisfied with how } \\
\text { life turned out so } \\
\text { far }\end{array}$ & Health & $\begin{array}{l}\text { Feeling } \\
\text { optimistic }\end{array}$ \\
\hline Important to compare & $\begin{array}{l}-0.094 * * * \\
(0.013)\end{array}$ & $\begin{array}{l}-0.123 * * * \\
(0.020)\end{array}$ & $\begin{array}{l}-0.081^{* * *} \\
(0.014)\end{array}$ & $\begin{array}{l}-0.012^{* * *} \\
(0.004)\end{array}$ & $\begin{array}{l}-0.040^{* * *} \\
(0.005)\end{array}$ \\
\hline Observations & 14942 & 14983 & 14983 & 14973 & 14983 \\
\hline \multirow[t]{2}{*}{ R-squared } & 0.17 & 0.061 & 0.038 & 0.158 & 0.054 \\
\hline & $\begin{array}{c}\text { Felt depressed, how } \\
\text { often past week }\end{array}$ & $\begin{array}{c}\text { Satisfied with } \\
\text { standard of living }\end{array}$ & $\begin{array}{l}\text { How satisfied with } \\
\text { job }\end{array}$ & $\begin{array}{c}\text { Paid } \\
\text { appropriately }\end{array}$ & $\begin{array}{c}\text { Living } \\
\text { comfortably }\end{array}$ \\
\hline Important to compare & $\begin{array}{l}0.022 * * * \\
(0.003)\end{array}$ & $\begin{array}{l}-0.108 * * * \\
(0.016)\end{array}$ & $\begin{array}{l}-0.140 * * * \\
(0.017)\end{array}$ & $\begin{array}{l}-0.119 * * * \\
(0.009)\end{array}$ & $\begin{array}{l}-0.038 * * * \\
(0.003)\end{array}$ \\
\hline Observations & 14983 & 14983 & 14983 & 14983 & 14963 \\
\hline R-squared & 0.083 & 0.118 & 0.024 & 0.127 & 0.371 \\
\hline
\end{tabular}

Notes: Each column corresponds to a separate regression. Other controls as in Table 5: log household income, 10 occupation dummies (one-digit ISCO), self-employed, 3 age dummies, 3 education dummies, 5 marital status dummies, ever had children, and country dummies. ${ }^{*}, * *$ and $* * *$ denote significance at the $10 \%, 5 \%$ and $1 \%$ levels respectively. Standard errors in parentheses are clustered by country.

Interpreting these comparison estimates in the light of relative utility theory, as in Section 2, the well-being effect of relative income $\left(\mathrm{y}_{\mathrm{i}}-\mathrm{y}^{*}\right)$ is predominantly negative, i.e. most people compare upward and signal effects do not outweigh status effects. One implication of this interpretation is that the richer should report a more positive correlation with comparison intensity (as they are more likely to come out well from any such comparison). To check, we interacted a dummy for earning more than the country median income with comparison intensity to the specification in column (1) of Table 7, controlling for the main effect of both variables. The interaction term attracted a positive and significant coefficient $(0.039$ (0.012)): the well-being effect of comparisons is less negative for the richer.

While the above results are consistent with more intense comparisons causing reduced well-being, there is of course another reverse-causality interpretation: unhappy people may compare to others more in order to explain and justify their lower well-being. Equally, those who are unhappy with their income but who are also upwardly mobile may be more likely to compare upward as part of a general self-improvement strategy. While one of the keystones of the work in this paper has been the heterogeneity of comparison intensity, we are not able to conclude as to any causality in this cross- 
section data. The identification of good instruments for comparison intensity that would enable us to distinguish better between these rival interpretations is obviously not simple in this context.

\subsection{Reference groups and happiness}

While those who compare more are less happy, the magnitude of this correlation depends on the direction of comparisons: the results in columns 3 and 4 of Table 7 show that those who compare to colleagues are significantly happier than those who choose friends (or "others") as their benchmark. This holds whether the intensity of comparisons is controlled for or not.

Following Section 2, one interpretation of this correlation is that there is likely more of an information effect (regarding own future income) from work colleagues than from family or friends. However, we cannot exclude an alternative reading that the value of $\mathrm{y}_{\mathrm{i}}^{*}$ is not the same across reference groups. Specifically, if there are no information effects and the $\mathrm{y}_{\mathrm{i}}{ }^{*}$ of colleagues is systematically lower than the $\mathrm{y}_{\mathrm{i}}{ }^{*}$ of all other possible reference groups (so that the individual's relative income is higher), the well-being correlation with comparisons to colleagues will be more positive. As we do not have direct information on the level of these different $\mathrm{y}_{\mathrm{i}}{ }^{*}$ 's, we cannot evaluate the likelihood of this joint hypothesis.

These results concerning the welfare impact of the intensity and the direction of comparisons naturally raise the question whether those for whom comparisons are very important are less happy when they compare to a certain group rather to another. Experiments along theses lines show that individuals who declare that comparisons are important are more happy than the average when they compare to colleagues rather than to other reference groups (the coefficient on the interaction between comparison intensity and the dummy for "colleagues", added to the specification in column (4) of Table 7 , is $0.123(0.070)$ when the omitted category is "other", controlling for the main effects of both variables). 


\section{Income comparisons, Happiness and the Demand for Redistribution}

If people who compare more are also less happy, and if this relationship is causal (which we cannot however prove here), we might expect attitudes to income inequality to be associated with income comparisons. The two notions are of course different, as income comparisons refer to the specific income gap between individual income and the income of some relevant others, whereas income inequality refers to the entire distribution of income in society. However, those who suffer from low individual relative income might in turn be more in favour of income redistribution, at least for purely self-regarding reasons.

We measure the demand for redistribution via the following ESS question: "Please say to what extent you agree or disagree with each of the following statements: The government should take measures to reduce differences in income levels". The distribution of this variable in our 18-country regression sample is shown in Table 9 below.

Table 9. "The government should take measures to reduce differences in income levels"

\begin{tabular}{lcc}
\hline & Frequency & Weighted \% \\
\hline Strongly disagree & 483 & 2.57 \\
Disagree & 2437 & 12.94 \\
Neither agree nor disagree & 2957 & 15.7 \\
Agree & 8003 & 42.5 \\
Strongly agree & 4951 & 26.29 \\
Total & 18832 & 100 \\
\hline Note: Weighted statistics. Sample. In paid work aged between 16 and 65.
\end{tabular}

Note: Weighted statistics. Sample: In paid work aged between 16 and 65.

Preliminary estimates (not shown) of this demand for redistribution showed that, as often found (Alesina et al., 2004), the richer and those in more professional occupations, the self-employed, men, the younger, the married, the more educated and those who have never had children are less in favour of income redistribution. The estimates also include country fixed effects, which capture, amongst other things, the actual level of income redistribution in each country. The coefficients on these country 
dummies reveal that Scandinavians are less in favour of reducing income differences, as compared to those in Continental Europe, while Southern and Eastern Europeans are more in favour. This is consistent with individuals interpreting the redistribution question as asking whether they are in favour of "more redistribution than currently takes place”.

Column 1 of Table 10 shows that the more people consider income comparisons to be important, the more they are in favour of (additional) income redistribution by the State. However, columns 2 and 3 qualify this result and show that it is comparisons to family members and "others", much more than to colleagues, that are linked with a greater demand for income redistribution.

Table 10. Comparisons and the demand for income redistribution by the State (OLS)

\begin{tabular}{llll}
\hline \multicolumn{3}{l}{ The government should take measures to reduce differences } & \multicolumn{3}{l}{ income levels } \\
\hline \multirow{2}{*}{ Log household income } & 1 & 2 & 3 \\
& $-0.158^{* * *}$ & $-0.161^{* * *}$ & $-0.159^{* * *}$ \\
Important to compare & $(0.022)$ & $(0.023)$ & $(0.022)$ \\
& $0.027^{* * *}$ & & $0.027^{* * *}$ \\
Comparison direction (Omitted: Don't compare) & & $(0.008)$ \\
Work colleagues & & $0.049^{* *}$ & -0.004 \\
& & $(0.021)$ & $(0.020)$ \\
Family members & $0.143^{* * *}$ & $0.105^{* * *}$ \\
& & $(0.035)$ & $(0.036)$ \\
Others & & $0.120^{* *}$ & 0.052 \\
& & $(0.047)$ & $(0.045)$ \\
Friends & & 0.051 & -0.006 \\
& & $(0.038)$ & $(0.038)$ \\
Observations & 14855 & 14681 & 14681 \\
R-squared & 0.128 & 0.127 & 0.128 \\
\hline
\end{tabular}

Notes: Other controls as in Table 5: 10 occupation dummies (one-digit ISCO), self-employed, 3 age categories, 3 education categories, 5 marital status dummies, ever had children, and country dummies. $*, * *$ and $* * *$ denote significance at the $10 \%, 5 \%$ and $1 \%$ levels respectively. Standard errors in parentheses are clustered by country.

The demand for income redistribution therefore seems to follow the same pattern as well-being: the intensity of comparisons is associated with a greater demand for redistribution and less happiness; comparisons to colleagues produce the weakest 
demand for income redistribution, and are associated with the "happiest" type of comparers.

As above, we can look for heterogeneity in the demand for redistribution. In a number of cases, the groups that are identified as being more in favour of income distribution are the same as those that compare more (consistent with the first column of Table 10). Comparison intensity and the demand for redistribution are both lower for richer individuals, the self-employed and the married (which groups are also happier); the same is true for those who watch less than one hour of TV per weekday. However, this equivalence does not always hold. For example, those with higher education compare more but are less in favour of redistribution. Individuals who agree that "it is important to be rich and buy expensive things" compare more but are less in favour of income redistribution, while the opposite holds for those who work in firms with less than 100 employees. These findings on different "types" of individuals are summarised in Table 11 below.

Although it is obviously difficult to generalize, a number of these findings are consistent with a greater intensity of income comparisons being associated with a greater demand for redistribution when the latter is partly self-regarding, in the sense that the individuals themselves would likely benefit from it.

Table 11. Heterogeneity in Income Comparisons, Happiness and the Demand for Income Redistribution (OLS).

\begin{tabular}{|l|c|c|l|c|c|}
\hline \multicolumn{1}{|c|}{ Variables of interest } & $\begin{array}{c}\text { Weighted } \\
\text { \% }\end{array}$ & $\begin{array}{c}\text { Comparison } \\
\text { intensity }\end{array}$ & Direction of comparison & Happy & $\begin{array}{c}\text { In favour of } \\
\text { income } \\
\text { redistribution }\end{array}$ \\
\hline Male & 47.3 & + & $\begin{array}{l}\text { Colleagues, friends+ } \\
\text { Family- }\end{array}$ & - & - \\
\hline Married & 56.6 & - & $\begin{array}{l}\text { Family+, } \\
\text { Colleagues and friends - }\end{array}$ & + & - \\
\hline Never in couple & 32.3 & + & & & \\
\hline Log household income & N/A & - & & + & - \\
\hline Over 25 years old & 88.4 & 0 & & - & + \\
\hline Tertiary education & 23.6 & + & $\begin{array}{l}\text { Colleagues, friends, } \\
\text { others + } \\
\text { Family - }\end{array}$ & 0 & - \\
\hline Self-employed & 9.5 & - & Colleagues + \\
Total working hours & N/A & + & $\begin{array}{l}\text { Colleagues- } \\
\text { Family and friends + }\end{array}$ & - & - \\
\hline Small firm & 52 & - & Friends + & + \\
\hline City & 60 & + & & 0 & 0 \\
\hline
\end{tabular}




\begin{tabular}{|c|c|c|c|c|c|}
\hline Never had a paid job & 9 & - & $\begin{array}{l}\text { Colleagues - } \\
\text { Friends and family + }\end{array}$ & + & 0 \\
\hline $\begin{array}{l}\text { Household main income source: } \\
\text { - transfers } \\
\text { - self employment } \\
\text { - wages }\end{array}$ & $\begin{array}{l}18 \\
6.5 \\
75\end{array}$ & $\begin{array}{l}- \\
- \\
+\end{array}$ & $\begin{array}{l}\text { Friends }+ \\
\text { Friends }+ \\
\text { Colleagues }+\end{array}$ & $\begin{array}{l}- \\
0 \\
+\end{array}$ & $\begin{array}{l}0 \\
- \\
+\end{array}$ \\
\hline No internet access & 23 & - & Others + & 0 & + \\
\hline Watch TV more than 1 hour/day & 72 & + & Others + & $0-$ & + \\
\hline Important to be successful & 64.5 & + & Colleagues + & 0 & 0 \\
\hline Important to be rich & 33.7 & + & $\begin{array}{l}\text { Colleagues }+ \\
\text { Friends and others }+\end{array}$ & - & - \\
\hline
\end{tabular}

Notes: This table summarises the estimated coefficients on the variables indicated in the first column. Other controls as in Table 5: log household income, occupation dummies (one-digit ISCO), self-employed, 3 age dummies, 3 education dummies, 5 marital status dummies, ever had children, and country dummies.

This paper has not been able to prove causality. However, a direct reading of the results underlined above suggests that a society which becomes more comparison-conscious (due to greater competition on the labour market, for example, or greater emphasis or prevalence in the media of information about other people's lifestyles) will not only be, on average, less happy, but may also become more redistributive. At some level, this might be thought to be consistent with empirical work that has struggled to establish an unambiguous relationship between ex post income inequality and happiness.

\section{Conclusion}

This paper has analysed unprecedented direct evidence on the intensity and direction of income comparisons. Income comparisons are acknowledged as at least somewhat important by a majority of Europeans. Comparison intensity decreases with income, both across countries and within countries. Comparisons are associated with lower levels of happiness, but less so for those with higher incomes. These findings are consistent with a model of relative utility. The fact that the correlation between comparison intensity and happiness is negative suggests that income comparisons are mostly upward, and that status effects outweigh any positive signal effects from others' income. Regarding the direction of comparisons, colleagues are the most frequentlycited reference group. Those who compare to colleagues are also happier than those who compare to friends or other groups. 
Income comparisons are associated with a greater demand for income redistribution. This correlation is stronger for those who compare to family members and "others", rather than to their colleagues. These empirical findings are redolent of an information effect à la Hirschman (1977), whereby people compare to their colleagues in order to acquire information about their professional future. Comparisons to family members, friends or "other” groups obviously do not carry the same informational value.

The ESS data reveal substantial heterogeneity in the groups to which individuals compare. This diversity in comparison benchmarks seems to be partly endogenous, being closely related to the type of regular social interactions that respondents experience. For example, those who "socialize" more or who work in small firms compare less to their colleagues; those who don't have internet access compare less in general. However, our findings are not consistent with individuals endogenously choosing their comparison benchmark in order to maximize their well-being (selfenhancement). For instance, Southern Europeans compare more to family members even though this type of comparison is associated with lower well-being for them.

Income comparisons thus seem to be prevalent in Europe, and are significantly correlated with both well-being and political attitudes. There is moreover substantial heterogeneity in terms of both their intensity and direction. While this paper has provided novel information in this respect, some parts of the puzzle are still missing. In particular, the joint analysis of the income-comparison questions described here and some robust measure of reference group income itself would seem well-worth exploring. Equally, given the potential endogeneity of comparisons, causality remains to be established: either via instrumental variables, or in experimental settings. 


\section{References}

Alesina, A., Di Tella, R. and MacCulloch, R., (2004). "Inequality and happiness: Are Europeans and Americans different?” Journal of Public Economics, 88, 2009-2042.

Bygren, M. (2004). "Pay Reference Groups and Pay Satisfaction. What Do Workers Evaluate Their Pay Against" Social Science Research, 33, 206-224.

Cappelli, P. and Sherer, P. (1988), "Satisfaction, Market Wages and Labor Relations: An Airline Study”, Industrial Relations, 27, 56-73.

Clark A.E., Diener E., Georgellis T. and Lucas R. (2008b), "Lags and Leads in Life Satisfaction: A Test of the Baseline Hypothesis”, Economic Journal, 118, F222-243.

Clark A.E., Kristensen N. and Westergård-Nielsen N. (2009a), “Job Satisfaction and Co-worker Wages: Status or Signal?”, Economic Journal, 119, 430-447.

Clark, A.E. and Oswald, A (1996), "Satisfaction and Comparison Income”, Journal of Public Economics, 61, 359-81.

Clark, A.E., Etilé, F., Postel-Vinay, F., Senik, C., and van der Straeten, K. (2005). "Heterogeneity in Reported Well-Being: Evidence from Twelve European Countries". Economic Journal, 115, C118-C132.

Clark, A.E., Frijters, P. and Shields, M. (2008a). "Relative Income, Happiness and Utility: An Explanation for the Easterlin Paradox and Other Puzzles". Journal of Economic Literature, 46, 95-144.

Clark, A.E., Masclet, D. and Villeval, M.-C. (2009b). "Effort and Comparison Income". Industrial and Labor Relations Review, forthcoming.

Di Tella, R. MacCulloch, R. and Oswald, A.J. (2003). "The Macroeconomics of Happiness”. Review of Economics and Statistics, 85, 809-827.

Duesenberry J., 1949, Income, Saving and the Theory of Consumer Behavior, Cambridge (Mass.) Harvard University Press. 
Easterlin, R., 1974. "Does economic growth improve the human lot? Some empirical evidence”. In David, R. Reder, R. (Eds.). Nations and Households in Economic Growth: Essays in Honor of Moses Abramovitz. New York: Academic Press.

Easterlin, R., 1995. "Will raising the incomes of all improve the happiness of all?" Journal of Economic Behavior and Organization, 27, 35-47.

Falk, A. and Knell, M. (2004), “Choosing the Joneses: Endogenous goals and reference standards”, Scandinavian Journal of Economics, 106, 417-435.

Falk, A., and Ichino, A. (2006). "Clean Evidence on Peer Pressure". Journal of Labor Economics, 24, 39-57.

Fehr, E., and Schmidt, K. (1999). "A Theory of Fairness, Competition and Cooperation". Quarterly Journal of Economics, 114, 817-868.

Ferrer-i-Carbonell, A. (2005), "Income and well-being: An empirical analysis of the comparison income effect”, Journal of Public Economics, 89, 997-1019.

Ferrer-i-Carbonell A. and Frijters P. (2004), "How Important is Methodology for the Estimates of the Determinants of Happiness?”, Economic Journal, 114, 641-659.

Helliwell, J.F., and Huang, H. (2009). "How's the Job? Well-Being and Social Capital in the Workplace". Industrial and Labor Relations Review, forthcoming.

Heston A., Summers R. and Aten B. (2006), "Penn World Table Version 6.2”, Center for International Comparisons of Production, Income and Prices at the University of Pennsylvania.

Hirschman A., with Rothschild M. (1973), “The Changing Tolerance for Income Inequality in the Course of Economic Development”, Quarterly Journal of Economics, 87, 544-566.

Huppert, H., Marks, N., Clark, A.E., Siegrist, J., Stutzer, A., Vittersø, J., and Wahrdorf, M. (2009). "Measuring well-being across Europe: Description of the ESS Well-being Module and preliminary findings". Social Indicators Research, 91, 301-315. 
Knight, J. and Song, L., 2006, "Subjective well-being and its determinants in rural China”, University of Nottingham, mimeo.

Luttmer E. (2005), “Neighbors as Negatives: Relative Earnings and Well-Being”, Quarterly Journal of Economics, 120, 963-1002.

MacBride M. (2001). "Relative-Income Effects on Subjective Well-being in the Crosssection”, Journal of Economic Behavior and Organization , 45, 251-278.

McBride, M. (2006). "An Experimental Study of Happiness and Aspiration Formation". University of California-Irvine, Mimeo.

Senik C. (2004), "When Information Dominates Comparison. Learning from Russian Subjective Panel Data”, Journal of Public Economics, 88, 2099-2133.

Senik C. (2008), “Ambition and Jealousy. Income Interactions in the "Old Europe” versus the "New Europe” and the United States”, Economica, 75, 495-513.

Senik C. (2009), "Direct Evidence on Income Comparisons and their Welfare Effects”, Journal of Economic Behavior and Organization, forthcoming.

Wood, J. and K. Taylor (1991), “Serving Self-Relevant Goals Through Social Comparison”, in: Suls, J. and T. A. Wills (eds.), Social Comparison: Contemporary Theory and Research, New Jersey: Lawrence Erlbaum Associates, Inc., Publishers, 2349. 


\section{Appendix. Weighted Descriptive Statistics. Regression Sample.}

Main controls and interactions terms

\begin{tabular}{|c|c|}
\hline & Percentage \\
\hline Male & 51.6 \\
\hline \multicolumn{2}{|l|}{ Education } \\
\hline Primary & 26.5 \\
\hline Secondary & 43.9 \\
\hline Tertiary & 29.5 \\
\hline \multicolumn{2}{|l|}{ Marital status } \\
\hline Married & 61.2 \\
\hline Separated & 9.4 \\
\hline Widow & 1.6 \\
\hline Never in couple & 27.8 \\
\hline \multicolumn{2}{|l|}{ Age } \\
\hline Under 25 & 11.7 \\
\hline $25-50$ & 63.3 \\
\hline Over 50 & 25.0 \\
\hline Ever given birth to a child? & 67.9 \\
\hline Self-employed & 12.0 \\
\hline \multicolumn{2}{|l|}{ Household income per month } \\
\hline Less than 150 Euros & 2.26 \\
\hline 150 to 300 Euros & 3.95 \\
\hline 300 to 500 Euros & 6.37 \\
\hline 500 to 1000 Euros & 8.46 \\
\hline 1000 to 1500 Euros & 8.96 \\
\hline 1500 to 2000 Euros & 10.32 \\
\hline 2000 to 2500 Euros & 10.83 \\
\hline 2500 to 3000 Euros & 11.6 \\
\hline 3000 to 5000 Euros & 21.29 \\
\hline 5000 to 7500 Euros & 10.16 \\
\hline Over 7500 Euros & 5.8 \\
\hline \multicolumn{2}{|l|}{ Occupation } \\
\hline Armed forces & 0.3 \\
\hline Legislators senior officials and managers & 8.9 \\
\hline Professionals & 16.0 \\
\hline Technicians and associate professionals & 18.2 \\
\hline Clerks & 10.9 \\
\hline Service workers and shop and market sales workers & 15.6 \\
\hline Skilled agricultural and fishery workers & 2.5 \\
\hline Craft and related trades workers & 12.5 \\
\hline Plant and machine operators and assemblers & 7.4 \\
\hline Elementary occupations & 7.7 \\
\hline
\end{tabular}


Household main income source:

- Wages

- Self-employment

- Transfers

3.2

- Capital

No internet access

Small firm <100 employees

City (versus country villages or countryside)

Watch TV less than 1 hour per weekday

It is important to:

- be rich and have money and expensive things 32.9

- be successful and that people recognize achievements

"How often do you meet socially with friends, relatives or work colleagues?”

Never

Less than once a month

Once a month

Several times a month $\quad 18.4$

Once a week 19.0

Several times a week $\quad 30.2$

Every day 18.5

Total hours worked weekly (0-100) 39.2

Satisfaction question (answers in ascending order):

$\begin{array}{ll}\text { Satisfied with life as a whole (0-10) } & 7.1\end{array}$

Satisfied with how life turned out so far (0-10) 7.2

How is your health in general? (0-10) 4.0

Feel optimistic about future (0-5) 3.7

How often felt depressed past week (0-4) 1.4

Satisfied with standard of living (0-10) 6.9

$\begin{array}{ll}\text { Satisfied with job (0-10) } & 7.1\end{array}$

Paid appropriately considering efforts and achievements (0-5) 3.1

Living comfortably on present income? (0-4) 3.2

Note: Weighted statistics. Sample: In paid work aged between 16 and 65. 